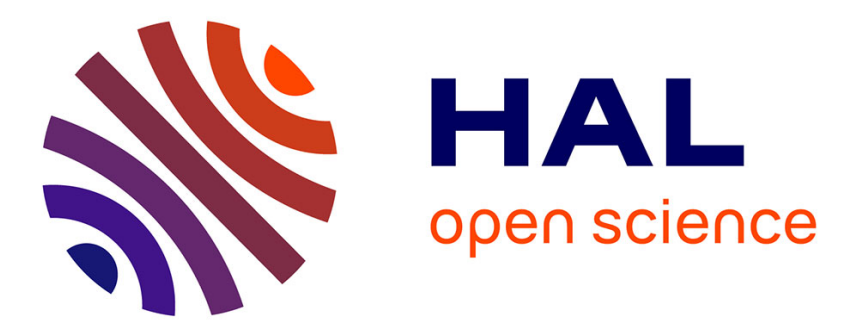

\title{
Exceptionally preserved soft parts in fossils from the Lower Ordovician of Morocco clarify stylophoran affinities within basal deuterostomes.
}

Bertrand Lefebvre, Thomas E. Guensburg, Emmanuel L.O. Martin, Rich Mooi, Elise Nardin, Martina Nohejlová, Farid Saleh, Khaoula Kouraïss, Khadija El Hariri, Bruno David

\section{To cite this version:}

Bertrand Lefebvre, Thomas E. Guensburg, Emmanuel L.O. Martin, Rich Mooi, Elise Nardin, et al.. Exceptionally preserved soft parts in fossils from the Lower Ordovician of Morocco clarify stylophoran affinities within basal deuterostomes.. Geobios, 2019, 52, pp.27-36. hal-02014812

\section{HAL Id: hal-02014812 https://hal.science/hal-02014812}

Submitted on 12 Nov 2020

HAL is a multi-disciplinary open access archive for the deposit and dissemination of scientific research documents, whether they are published or not. The documents may come from teaching and research institutions in France or abroad, or from public or private research centers.
L'archive ouverte pluridisciplinaire HAL, est destinée au dépôt et à la diffusion de documents scientifiques de niveau recherche, publiés ou non, émanant des établissements d'enseignement et de recherche français ou étrangers, des laboratoires publics ou privés. 


\title{
Manuscript Details
}

\section{Manuscript number}

Title

Article type
GEOBIO_2018_75

Exceptionally preserved soft parts in fossils from the Lower Ordovician of Morocco clarify stylophoran affinities within basal deuterostomes

\begin{abstract}
The extinct echinoderm clade Stylophora consists of some of the strangest known deuterostomes. Stylophorans are known from complete, fully articulated skeletal remains from the middle Cambrian to the Pennsylvanian, but remain difficult to interpret. Their bizarre morphology, with a single appendage extending from a main body, has spawned vigorous debate over the phylogenetic significance of stylophorans, which were long considered modified but bona fide echinoderms with a feeding appendage. More recent interpretation of this appendage as a posterior "tail-like" structure has literally turned the animal back to front, leading to consideration of stylophorans as ancestral chordates, or as hemichordate-like, early echinoderms. Until now, the data feeding the debate have been restricted to evaluations of skeletal anatomy. Here, we apply novel elemental mapping technologies to describe, for the first time, soft tissue traces in stylophorans in conjunction with skeletal molds. The single stylophoran appendage contains a longitudinal canal with perpendicular, elongate extensions projecting beyond hinged biserial plates. This pattern of soft tissues compares most favorably with the hydrocoel, including a water vascular canal and tube feet found in all typical echinoderms. Presence of both calcite stereom and now, an apparent water vascular system, support echinoderm and not hemichordate-like, affinities.
\end{abstract}

Keywords

Corresponding Author

Corresponding Author's Institution

Order of Authors

Suggested reviewers deuterostomes; echinoderms; Fezouata Lagerstätte; Morocco; phylogeny.

Bertrand Lefebvre

CNRS

Bertrand Lefebvre, Thomas E. Guensburg, Emmanuel L.O. Martin, Rich Mooi, Elise Nardin, Martina Nohejlova, Farid Saleh, Khaoula Kouraiss, Khadija El Hariri, Bruno David

Colin Sumrall, James Sprinkle, Derek Briggs

\section{Submission Files Included in this PDF}

\author{
File Name [File Type] \\ Lefebvre_cover letter.pdf [Cover Letter] \\ Lefebvre et al._MS.docx [Manuscript File] \\ Lefebvre et al._Fig. 1.tif [Figure] \\ Lefebvre et al._Fig. 2.tif [Figure] \\ Lefebvre et al._Fig. 3.tif [Figure] \\ Lefebvre et al._Fig. 4.tif [Figure] \\ Lefebvre et al._Fig. 5.tif [Figure] \\ Lefebvre et al._Fig. 6.tif [Figure] \\ Lefebvre et al._Fig. 7.tif [Figure] \\ Lefebvre et al._Fig. 8.tif [Figure] \\ Lefebvre et al._Fig. 9.tif [Figure]
}

To view all the submission files, including those not included in the PDF, click on the manuscript title on your EVISE Homepage, then click 'Download zip file'. 


\section{Research Data Related to this Submission}

There are no linked research data sets for this submission. The following reason is given: No data was used for the research described in the article 


\section{Exceptionally preserved soft parts in fossils from the Lower Ordovician of}

2 Morocco clarify stylophoran affinities within basal deuterostomes

4 Bertrand Lefebvre ${ }^{\text {a,*}}{ }^{*}$, Thomas E. Guensburg ${ }^{\text {b }}$, Emmanuel L.O. Martin a , Rich Mooi ${ }^{\text {c }}$, Elise

5 Nardin ${ }^{\mathrm{d}}$, Martina Nohejlova a, Farid Saleh ${ }^{\text {a, }}$ Khaoula Kouraïss ${ }^{\mathrm{e}}$, Khadija El Hariri e, Bruno

6 David $^{\mathrm{f}, \mathrm{g}}$

$7 \quad$ a UMR CNRS 5276 LGLTPE, Université Claude Bernard Lyon 1, F-69622 Villeurbanne cedex, France

$8 \quad{ }^{b}$ IRC, Field Museum, Chicago, IL 60605-2496, USA

$9{ }^{c}$ Department of Invertebrate Zoology and Geology, California Academy of Sciences, San Francisco, California $10 \quad 94118-4503$, USA

11 d UMR CNRS-IRD-UPS 5563 Géosciences Environnement Toulouse, Observatoire Midi-Pyrénées, F-31400

12 Toulouse, France

13 e Département des Sciences de la Terre, Faculté des Sciences et Techniques-Guéliz, Université Cadi Ayyad, 40000

14 Marrakesh, Morocco

15 fUMR CNRS 6282 Biogéosciences, Université de Bourgogne Franche-Comté, F-21000 Dijon, France

16 guséum National d'Histoire naturelle, F-75005 Paris, France

$18 *$ Corresponding author:

19 E-mail address: bertrand.lefebvre@univ-lyon1.fr

21 ABSTRACT 
The extinct echinoderm clade Stylophora consists of some of the strangest known deuterostomes.

24 Stylophorans are known from complete, fully articulated skeletal remains from the middle

1

2 Cambrian to the Pennsylvanian, but remain difficult to interpret. Their bizarre morphology, with a single appendage extending from a main body, has spawned vigorous debate over the phylogenetic significance of stylophorans, which were long considered modified but bona fide echinoderms with a feeding appendage. More recent interpretation of this appendage as a posterior "tail-like" structure has literally turned the animal back to front, leading to consideration of stylophorans as ancestral chordates, or as hemichordate-like, early echinoderms. Until now, the data feeding the debate have been restricted to evaluations of skeletal anatomy. Here, we apply novel elemental mapping technologies to describe, for the first time, soft tissue traces in stylophorans in conjunction with skeletal molds. The single stylophoran appendage contains a longitudinal canal with perpendicular, elongate extensions projecting beyond hinged biserial plates. This pattern of soft tissues compares most favorably with the hydrocoel, including a water vascular canal and tube feet found in all typical echinoderms. Presence of both calcite stereom and now, an apparent water vascular system, support echinoderm and not hemichordatelike, affinities.

Keywords: deuterostomes, echinoderms, Fezouata Lagerstätte, Morocco, phylogeny

\section{Introduction}


Phylogenetic relationships among the main clades of deuterostomes (Swalla and Smith, 2008;

Erwin et al., 2011; David and Mooi, 2014) and in particular, the earliest chordates (including the vertebrates) (Jefferies, 1986; Holland et al., 2015; Janvier, 2015) represent long-debated issues. In recent years, however, the combination of molecular, embryological, and anatomical data has made it possible to establish a robust phylogeny for extant deuterostomes. With the Hemichordata (acorn worms), the echinoderms (sea lilies, starfish, sea urchins, and related forms) are now considered to belong to a clade, the Ambulacraria, as the sister-group of chordates (cephalochordates, tunicates and vertebrates) (Bottjer et al., 2006; Swalla and Smith, 2008; David and Mooi, 2014; Holland et al., 2015; Janvier, 2015; Lowe et al., 2015). This phylogenetic scenario provides insights not only into the distinctive morphological features (apomorphies) acquired within each clade of deuterostomes, but also into the primitive characters (plesiomorphies) inherited from their common ancestors (Bottjer et al., 2006; Swalla and Smith, 2008; David and Mooi, 2014; Lowe et al., 2015). For example, the occurrence of gill slits in both extant hemichordates and chordates strongly supports the view that these structures were very likely present in earliest deuterostomes (Smith, 2005; Bottjer et al., 2006; Swalla and Smith, 2008; Lowe, 2015). Their absence in echinoderms is most parsimoniously regarded as a secondary loss during the course of echinoderm evolution (Smith, 2005; Bottjer et al., 2006; Swalla and Smith, 2008; Zamora and Rahman, 2014), or perhaps at the origin of the phylum itself (Mooi and David, 1998, 2008).

Integrating fossil data into the phylogeny of deuterostomes offers the opportunity to document the sequential acquisition of key characters through time and to provide minimum dates for lineage divergences. The interpretation of the earliest known deuterostomes (Shu et al., 2001, 2004; Caron et al., 2010, 2013) (Cambro-Ordovician, 541-443 Myr) is particularly challenging 
because their morphologies are often bizarrely unlike those of modern forms, with unexpected combinations of anatomical features. Along with cambroernids (Caron et al., 2010), conodonts (Briggs, 1992), vetulicolians (Shu et al., 2001) and vetulicystids (Shu et al., 2004), stylophorans belong to the bestiary of extinct, enigmatic early deuterostomes.

Stylophorans (cornutes and mitrates), a group of unusual middle Cambrian-Pennsylvanian (509-300 Myr) fossils, are small (typically one or two centimeters in length), bipartite organisms consisting of a single, articulated appendage inserted into a flattened, asymmetric to bilaterally symmetric body made of a multiplated, internal skeleton, or test (Ubaghs, 1968; Clausen and Smith, 2005; Smith, 2005; David et al., 2000; Dominguez et al., 2002; Lefebvre, 2003) (Fig. 1A, C). The appendage comprises two distinct parts: a highly flexible proximal region (partially inserted into the test) of telescopic, imbricate rings; and a relatively stiff distal region consisting of opposing, delicate biserial platelets mounted on massive, uniserial elements (ossicles). The two platelet biseries form a roof over a longitudinal median groove running along the upper surfaces of the ossicles. Some interpretations suggest that the biserial platelets are fixed (Fig. 1F), but others show them as hinged, movable elements, much like cover plates in modern sea lilies and their kin (crinoids) (Fig. 1C). In life, the test likely contained the viscera, and in some taxa, bears a series of pores interpreted either as respiratory (Ubaghs, 1968; David et al., 2000; Lefebvre, 2003) or pharyngeal structures (Jefferies, 1986; Dominguez et al., 2002; Shu et al., 2004; Clausen and Smith, 2005; Smith, 2005; Bottjer et al., 2006) (Fig. 1A, C). Both the appendage and the test consist of numerous calcitic skeletal elements possessing the same microstructure (called stereom) found in all echinoderms (Ubaghs, 1968; Jefferies, 1986; David et al., 2000; Dominguez et al., 2002; Lefebvre, 2003; Clausen and Smith, 2005; Smith, 2005; Bottjer et al., 2006; Zamora and Rahman, 2014). 
The phylogenetic position of stylophorans within deuterostomes has been a contentious matter

92 for decades. In the early 1960s, the stylophoran appendage was interpreted as a feeding arm, comparable in morphology to the feeding structures of various extant echinoderms (Ubaghs, 1968; David et al., 2000; Lefebvre, 2003). In this hypothesis, stylophorans are considered bona fide echinoderms, with their appendage bearing a single ambulacral ray of the water vascular system (Figs. 1A-C, 2). In the late 1960s, the stylophoran appendage was reinterpreted as a chordate-like tail, containing a notochord and serially arranged muscle blocks (Jefferies, 1986; Dominguez et al., 2002). Thereby, stylophorans were designated calcichordates, ancestral members of all three modern chordate lineages. This interpretation implies that the stereom skeleton of extant echinoderms was an apomorphy of all deuterostomes and therefore secondarily and independently lost in all lineages with the exception of echinoderms. Most recently, the stylophoran appendage has been interpreted as a muscular, hemichordate-like stalk (Shu et al., 2004; Clausen and Smith, 2005; Smith, 2005; Bottjer et al., 2006; Swalla and Smith, 2008; Caron et al., 2010) (Figs. 1D-F, 2). In this interpretation, stylophorans remained echinoderms (because of the presence of the distinctive stereom), but are among the earliest members of the phylum, because they retain plesiomorphic features lost in all more derived taxa (e.g., locomotory stalk), and lack apomorphies present in more derived taxa (e.g., water vascular system).

Two basic assumptions of the calcichordate interpretation have previously been falsified. First, the purported sister-group relationship between echinoderms and chordates was not confirmed by molecular phylogenetics, which indicated that echinoderms are more closely related to hemichordates than they are to chordates (Bottjer et al., 2006; Swalla and Smith, 2008; Erwin et al., 2011; Lowe et al., 2015). Second, available evidence supports the view that stereom 
114 is an echinoderm synapomorphy that first appeared in the early Cambrian (Bottjer et al., 2006;

115 Kouchinsky et al., 2012; Zamora and Rahman, 2014). The last two remaining, current

116 hypotheses both agree that stylophorans are echinoderms (Fig. 2), but differ markedly in the

117 interpretation of their appendage: feeding arm constructed like a typical echinoderm ray [H1]

118 versus tail constructed like a hemichordate-like stalk [H2].

119 Here we report the first evidence for soft part preservation in stylophorans. These data make it 120 possible to test, for the first time, soft anatomies predicted by $\mathrm{H} 1$ and $\mathrm{H} 2$. The feeding arm

121 hypothesis (H1) requires that: (1) the longitudinal median groove contained a water vascular 122 canal, with lateral tube feet; (2) biserial platelets are cover plates that opened to expose the tube

123 feet; (3) the mouth was located at the proximal end of the food groove; and (4) the fore-gut

124 (esophagus) was located within the proximal rings. The locomotory stalk scenario (H2) implies

125 that: (1) the longitudinal median groove contained a peduncular nerve; and (2) biserial platelets

126 are integrated, contiguous body wall elements sutured to each other so as to enclose a coelom.

127

128

129

130

131

132

133

134

135

136

\section{Material and methods}

All figured specimens are housed in the collections of Cadi-Ayyad University (Faculté des Sciences et Techniques, Guéliz), Marrakesh, Morocco. Locality details are indicated on specimen labels, and can be provided on request. Specimens were prepared with scalpels and needles under high magnification using a Zeiss SteREO Discovery.V8 stereomicrocope. Interpretative drawings were made using a camera lucida attached to a Zeiss SteREO Discovery.V8 stereomicroscope. Photographs were made with a Zeiss AxioCam MRc5 digital 
camera mounted on a Zeiss SteREO Discovery.V8 stereomicroscope. Digital photographs were processed in Adobe Photoshop Elements 9. Figs. 3A-B and Figs. S2A, S4A-B are composite images stitched together using Adobe Photoshop Elements 9. Elemental composition was analysed in a FEI Quanta 250 scanning electron microscope (SEM) equipped with an energy Xray analyser (EDX) at the Centre Technologique des Microstructures, plateforme de l'Université Claude Bernard Lyon 1.

\section{Results}

Stylophorans with soft parts were collected in the Lower Ordovician Fezouata KonservatLagerstätte, in a small excavation along the western flank of Bou Izargane hill, approximately 18 km north of Zagora (central Anti-Atlas, Morocco; Fig. 3). Here, the Fezouata Shale corresponds to a 1,000 m-thick, repetitive succession of argillaceous siltstones, unconformable over the middle Cambrian sandstones of the Tabanite Group (Destombes et al., 1985; Martin et al., 2016). The excavation is approximately $270 \mathrm{~m}$ above the base of the Ordovician series and within the lower stratigraphic interval (about $80 \mathrm{~m}$ thick) yielding soft-bodied faunas typical of the Fezouata Biota (Vinther et al., 2008, 2017; Van Roy et al., 2010, 2015; Van Roy and Briggs, 2011; Lefebvre et al., 2016; Martin et al., 2016) (Fig. 3). Nearby graptolites indicate a late Tremadocian age (A. murrayi Zone) (Gutiérrez-Marco and Martin, 2016; Lefebvre et al., 2016, 2018; Martin et al., 2016).

58 All specimens were collected from a single, small, $3 \mathrm{~cm}$-thick lens of dark blue mudstones. Three fossiliferous intervals occur within the lens: a lower layer with many densely packed, 
complete, and fully articulated marrellomorphs (Furca sp.; Fig. 4A), an intermediate horizon with a low-diversity assemblage of trilobites (Anacheirurus sp., Bavarilla sp.) with soft parts (Fig. 4B-C), and an upper, low-diversity assemblage comprising almost exclusively cornute stylophorans (more than 300 specimens belonging to two taxa, Hanusia n. sp. and Thoralicystis n. sp.; Figs 5-9). Deposition is interpreted as rapid burial of autochthonous communities by distal storm deposits in relatively shallow environmental conditions (Martin et al., 2016; Vaucher et al., 2016). In this level, arthropods and echinoderms are typically preserved as faint, flattened impressions on the dark rock. As in the Burgess Shale, echinoderm skeletons are indicated as impressions without preservation of actual stereom. In contrast, their soft tissues appear as colorful structures, resulting from the oxidation of original pyrite into yellow, red to purple iron oxide pseudomorphs (Figs. 5A, 6A, 7A, 8A, C). This type of preservation is not unique to the Bou Izargane cornutes (Vinther et al., 2008, 2017; Van Roy et al., 2010, 2015; Lefebvre et al., 2016). Similarly preserved soft parts (e.g. guts) have been described in arthropods (GutiérrezMarco et al., 2017), hyolithids (Marti Mus, 2016), and machaeridian annelids (Vinther et al., 2008) occurring in the same stratigraphic interval of the Fezouata Shale. In the cornutes, the identification and precise distribution of Fe-rich soft tissues were obtained by chemical analyses and elemental mapping under SEM (Figs. 5B, E, 6).

At least one specimen of Thoralicystis $\mathrm{n}$. sp. shows clear evidence of soft-bodied structures in the distal part of its appendage (Figs. 5-6). Preserved soft tissues consist of: (1) two superimposed longitudinal canals housed in the continuous, median groove on the upper surface of ossicles, and extending from the stylocone cavity (proximally) to the distal end of the appendage; (2) numerous small, lateral tube-like extensions branching regularly from the external longitudinal canal and protruding outward from between widely open, hinged plates. 
183 Several specimens of Thoralicystis n. sp. and Hanusia n. sp. exhibit strong evidence of soft 184 tissues preserved within the proximal part of their appendage (Figs. 7-8). All these specimens 185 display a spindle-shaped, elongate cavity extending throughout the proximal rings of the 186 appendage from the stylocone cavity (distally), to the main body cavity (proximally). All these

187 188 189 soft-bodied structures are described for the first time in stylophorans.

\section{Discussion}

\subsection{The stylophoran appendage is a feeding arm}

On the basis of this new evidence, it is possible to evaluate critically the two current interpretations of the stylophoran appendage. In the stalk model $(\mathrm{H} 2)$, the outermost of the two longitudinal canals could be interpreted as the peduncular nerve housed in a fully enclosed body cavity, or coelom. However, H2 must be rejected because of the presence of open plates that precludes such a coelom, and the presence of lateral extensions that branch regularly from the external longitudinal canal and protrude externally in between the open plates. This organisation is incompatible with that of a stalk-, or tail-like structure, but fits requisites of the feeding-arm model (H1). The evidence strongly supports H1, in which the external longitudinal canal is interpreted as an ambulacral canal of the water vascular system, and the lateral, tube-like structures as ambulacral tube feet (Figs. 5-6, 9), the morphology of which is strikingly similar to that of exceptionally preserved tube feet described from Paleozoic arm-bearing forms (Glass and Blake, 2004; Sutton et al., 2005; Glass, 2006; Clark et al., 2017). As a consequence, the mouth of 
stylophorans is most parsimoniously located at the proximal end of this ambulacral groove (Fig.

5C), the spindle-shaped cavity extending from the mouth (distally) and connected to the main body cavity (proximally) representing the anterior part of the gut (Figs. 5, 7-8). Comparison with the situation in the arms and pinnules of modern crinoids suggests that the internal longitudinal canal internal to the space above the water vascular system is a coelomic canal (Figs. 5-6). There is no evidence that what are interpreted here as tube feet represent some sort of musculature, because they project as free-standing structures extending from the longitudinal canal, and protrude outside of the body wall into the external medium.

Labyrinthic meshwork has been described in the proximal cavity of the stylocone (large, cone-shaped, uniserial ossicle located at the proximal end of the distal part of the appendage) of the primitive stylophoran Ceratocystis (middle Cambrian) (Clausen and Smith, 2005). Similar observations in extant echinoderms suggest that this labyrinthic microstructure was associated with muscle insertion, implying that the stylocone cavity once housed musculature with functionality similar to that in hemichordates. However, living echinoderms express muscles as well, so this trait is compatible with both H1 (Fig. 1B) and H2 (Fig. 1E), and cannot be used to provide evidence for or against either.

Finally, the putative locomotory function of the stylophoran appendage has been frequently considered as incompatible with its interpretation as a feeding arm and the presence of a watervascular canal (Rahman et al., 2009; Rozhnov and Parsley, 2017). As this is the case in many extant arm-bearing echinoderms (e.g. asteroids, ophiuroids, comatulids), it is very likely that stylophorans used their appendage not only for nutrition, but also locomotion (Lefebvre, 2003).

\subsection{Implications for echinoderm phylogeny}


Preserved soft tissues in cornutes from the Fezouata Shale provide strong evidence suggesting the existence of ambulacral structures in the stylophoran appendage. The evidence supports the 232 view that this extinct group of ambulacrarians possessed at least two of the major apomorphies supporting recognition of the phylum Echinodermata: (1) a multi-element endoskeleton, made of 234 calcitic plates displaying the typical, three-dimensional, stereomic microstructure; and (2) a 235 water vascular system. However, the precise phylogenetic position of stylophorans within 236 echinoderms remains so far unresolved because they do not display any evidence of the radial, 237 five-fold symmetry generally considered a synapomorphy of the phylum (Shu et al., 2004; 238 Smith, 2005; Bottjer et al., 2006; Swalla and Smith, 2008; Zamora and Rahman, 2014). If this 239 absence is original, stylophorans would then represent a relatively early branch of pre-radial 240 echinoderms (Ubaghs, 1968, 1975; Shu et al., 2004; Smith, 2005; Bottjer et al., 2006; Swalla and 241 Smith, 2008; Zamora and Rahman, 2014). Such an interpretation requires that anatomically 242 similar, arm-like, feeding structures were acquired independently in stylophorans in the middle 243 Cambrian, and again, in later forms such as asteroids and crinoids, in the Early Ordovician 244 (Ubaghs, 1968, 1975). (Kouchinsky et al., 2012; Zamora et al., 2013) and their unusual, flattened morphology more 248 parsimoniously suggest that stylophorans are relatively derived echinoderms descended from 249 pentaradial ancestors (David et al., 2000). This interpretation is supported by embryological data, 250 which provide no evidence suggesting that 5-part radial symmetry is preceded by stages with 251 fewer rays (Mooi and David, 2008). In this context, the possession of arm-like, ambulacral 
252 structures containing coelomic extensions other than the hydrocoel could represent an 253 apomorphy uniting stylophorans with forms such as crinoids (David et al., 2000; Lefebvre, 254 2003).

The exceptionally preserved cornute specimens from Morocco bring revolutionary new 259 evidence to consider. That evidence actually reverses the anterior-posterior axis suggested by 260 some very recent interpretations seeking to revive a modified version of the calcichordate 261 interpretation (Shu et al., 2001, 2004; Clausen and Smith, 2005; Smith, 2005; Bottjer et al., 2006; 262 Swalla and Smith, 2008; Zamora and Rahman, 2014). Since the early 2000s, molecular 263 phylogenies have strongly supported an ambulacrarian clade that unites hemichordates and 264 echinoderms as sister-group to the chordates (Bottjer et al., 2006; Swalla and Smith, 2008; David 265 and Mooi, 2014; Holland et al., 2015; Janvier, 2015; Lower et al., 2015). As a consequence of 266 this new phylogenetic framework, several authors reinterpreted stylophorans as early members of 267 the Echinodermata, morphologically extremely close to the last common ancestor of both 268 hemichordates and echinoderms (Shu et al., 2001, 2004; Clausen and Smith, 2005; Smith, 2005; 269 Bottjer et al., 2006; Swalla and Smith, 2008). In this interpretation, stylophorans would possess a 270 single echinoderm apomorphy: the calcite, stereom skeleton. They would not yet have acquired 271 two other significant echinoderm apomorphies: the water-vascular system and the radial, five272 fold symmetry. 
In a surprising parallel to the calcichordate hypothesis, stylophorans would share with other 274 (early) ambulacrarians and deuterostomes (1) a bipartite body organization, with a head and a muscular, locomotory tail (or stalk); and (2) the presence (plesiomorphic retention) of gill slits (Shu et al., 2001, 2004; Conway Morris, 2003; Clausen and Smith, 2005; Smith, 2005; Bottjer et al., 2006; Swalla and Smith, 2008; Caron et al., 2010; Conway Morris and Caron, 2012; Zamora and Rahman, 2014; Conway Morris et al., 2015). As a consequence, this interpretation of stylophorans as hemichordate-like, early echinoderms with a bipartite organization (anterior head and posterior, tail-like appendage) has in the last 15 years caused many comparisons of early deuterostomes to stylophorans, i.e. Herpetogaster and cambroernids (Caron et al., 2010), Pikaia and other putative early chordates (Donoghue et al., 2003; Gee, 2006; Conway Morris and Caron, 2012), vetulicolians (Shu et al., 2001; Conway Morris, 2003; Vinther et al., 2011; Ou et al., 2012), and vetulicystids (Shu et al., 2004; Conway Morris et al., 2015).

Our study demonstrates that: (1) stylophorans had a water-vascular system; and (2) that their appendage was not a locomotory, muscular tail. By bringing new, unequivocal evidence that the stylophoran appendage is an echinoderm feeding arm (comparable in morphology to a crinoid feeding arm) and not a hemichordate-like tail (or stalk), our discovery shows that the interpretation of these fossils as early echinoderms retaining features of basal ambulacrarians and/or hemichordates can be definitively rejected. In fact, any suggestion that stylophorans can tell us something about common ancestry of echinoderms with other deuterostomes is seriously compromised by the solid evidence that such conclusions rely on a reconstruction that has the animal the wrong way around. The bipartite body organization of stylophorans (theca and feeding arm) is not homologous to the bipartite body organization of Herpetogaster, vetulicolians, vetulicystids, early chordates and/or hemichordates (head and post-anal tail). 
Whatever the precise phylogenetic position of stylophorans within the Echinodermata, the

297 significance of the Fezouata fossils lies in the picture they give of the remarkable diversity 298 within the phylum throughout its evolution, and not of the supposed origins of the phylum itself.

\section{Acknowledgements} number ANR-11-BS56-0025), the CNRS-CNRST cooperation project VALORIZ (grant number 52943) and the CNRS-INSU TelluS-INTERRVIE 2018 project TAPHO FEZOUATA. Abel Prieur (Lyon 1 University, Villeurbanne) is recognized for discovering the level with exceptional preservation in the field, Jean Vannier (Lyon 1 University, Villeurbanne), for technical assistance with SEM, and both Bernard Pittet and Romain Vaucher (Lyon 1 University, Villeurbanne) for making available detailed sedimentological information on the locality. Ronald L. Parsley (Tulane University, New Orleans), Imran Rahman (Oxford University Museum of

312 Natural History), Sergei Rozhnov (Russian Academy of Sciences, Moscow), Samuel Zamora 313 (Instituto Geológico y Minero de España, Zaragoza) and five anonymous reviewers provided 314 insightful comments on several versions of the MS.

\section{$317 \quad$ References}


319 Bottjer, D.J., Davidson, E.H., Peterson, K.J., Cameron, R.A., 2006. Paleogenomics of 320 echinoderms. Science 314, 956-960.

321 Briggs, D.E.G., 1992. Conodonts - a major extinct group added to the vertebrates. Science 256, $322 \quad 1285-1286$.

323 Caron, J.B., Conway Morris, S., Shu, D.G., 2010. Tentaculate fossils from the Cambrian of 324 Canada (British Columbia) and China (Yunnan) interpreted as primitive deuterostomes. $325 \quad$ PlosOne 5, e9586.

326 Caron, J.B., Conway Morris, S., Cameron, C.B., 2013. Tubicolous enteropneusts from the 327 Cambrian period. Nature 495, 503-506.

328 Clark, E.G., Bhullar, B.A.S., Darroch, S.A.F., Briggs, D.E.G., 2017. Water vascular system $329 \quad$ architecture in an Ordovician ophiuroid. Biology Letters 13, 20170635

330 Clausen, S., Smith, A.B., 2005. Palaeoanatomy and biological affinities of a Cambrian 331 deuterostome (Stylophora). Nature 438, 351-354.

332 Conway Morris, S., 2003. The Cambrian "explosion" of metazoans and molecular biology: 333 would Darwin be satisfied? International Journal of Developmental Biology 47, 505-515.

334 Conway Morris, S., Caron, J.B., 2012. Pikaia gracilens Walcott, a stem-group chordate from the 335 Middle Cambrian of British Columbia. Biological Reviews 87, 480-512.

336 Conway Morris, S., Halgedahl, S.L., Selden, P., Jarrard, R.D., 2015. Rare primitive 337 deuterostomes from the Cambrian (Series 3) of Utah. Journal of Paleontology 89, 631-636.

338 David, B., Mooi, R., 2014. How Hox genes can shed light on the place of echinoderms among 339 the deuterostomes. EvoDevo 5, 22. 
David, B., Lefebvre, B., Mooi, R., Parsley, R.L., 2000. Are homalozoans echinoderms? An answer from the extraxial-axial theory. Paleobiology 26, 529-555.

Destombes, J., Hollard, H., Willefert, S., 1985. Lower Palaeozoic rocks of Morocco, in: Holland, C.H. (Ed.), Lower Palaeozoic Rocks of the World Volume 4: Lower Palaeozoic of North-Western and West-Central Africa. John Wiley \& Sons, Chichester, pp. 91-336.

Dominguez, P., Jacobson, A.G., Jefferies, R.P.S., 2002. Paired gill slits in a fossil with a calcite skeleton. Nature 417, 841-844.

Donoghue, P.C.J., Smith, M. P., Sansom, I.J., 2003. The origin and early evolution of chordates: molecular clocks and the fossil record, in: Donoghue, P.C.J., Smith, M.P. (Eds.), Telling the Evolutionary Time: Molecular Clocks and the Fossil Record. Taylor \& Francis, London, pp. $190-223$.

Erwin, D.H., Laflamme, M., Tweedt, S.M., Sperling, E.A., Pisani, D., Peterson, K.J., 2011. The Cambrian conundrum: early divergence and later ecological success in the early history of animals. Science 334, 1091-1097.

Gee, H., 2006. Careful with that amphioxus. Nature 439, 923-924.

Glass, A., 2006. Pyritized tube feet in a protasterid ophiuroid from the Upper Ordovician of Kentucky, U.S.A. Acta Palaeontologica Polonica 51, 171-184.

Glass, A., Blake, D.B., 2004. Preservation of tube feet in an ophiuroid (Echinodermata) from the Lower Devonian Hunsrück Slate of Germany and a redescription of Bundenbachia beneckei and Palaeophiomyxa grandis. Paläontologische Zeitschrift 78, 73-95.

Gutiérrez-Marco, J.C., Martin, E.L.O., 2016. Biostratigraphy and palaeoecoogy of Lower Ordovician graptolites from the Fezouata Shale (Moroccan Anti-Atlas). Palaeogeography Palaeoclimatology Palaeoecology 460, 35-49. 
363 Gutiérrez-Marco, J.C., Garcia-Bellido, D.C., Rábano, I., Sá, A.A., 2017. Digestive and 364 appendicular soft-parts, with behavioural implications, in a large trilobite from the Fezouata 365 Lagerstätte, Morocco. Scientific Reports 7, 39728.

366 Holland, N.D., Holland, L.Z., Holland, P.W.H., 2015. Scenarios for the making of vertebrates. $367 \quad$ Nature 520, 450-455.

368 Janvier, P., 2015. Facts and fancies about early fossil chordates and vertebrates. Nature 520, $369 \quad 483-489$.

370 Jefferies, R.P.S., 1986. The Ancestry of the Vertebrates. British Museum (Natural History), $371 \quad$ London.

372 Kouchinsky, A., Bengtson, S., Runnegar, B., Skovsted, C., Steiner, M., Vedrasco, M., 2012.

373 Chronology of early Cambrian biomineralization. Geological Magazine 149, 221-251.

374 Lefebvre, B., 2003. Functional morphology of stylophoran echinoderms. Palaeontology 46, 511$375 \quad 555$.

376 Lefebvre, B., El Hariri, K., Lerosey-Aubril, R., Servais, T., Van Roy, P., 2016. The Fezouata 377 Shale (Lower Ordovician, Anti-Atlas, Morocco): a historical review. Palaeogeography $378 \quad$ Palaeoclimatology Palaeoecology 460, 7-23.

379 Lefebvre, B., Gutiérrez-Marco, J.C., Lehnert, O., Martin, E.L.O., Nowak, H., Akodad, M., El 380 Hariri, K., Servais, T., 2018. Age calibration of the Lower Ordovician Fezouata Lagerstätte, $381 \quad$ Morocco. Lethaia 51, 296-311.

382 Lowe, C.J., Clarke, D.N., Medeiros, D.M., Rokhsar, D.S., Gerhart, J., 2015. The deuterostome 383 context of chordate origins. Nature 520, 456-465. 
Martí Mus, M., 2016. A hyolithid with preserved soft parts from the Ordovician Fezouata Konservat-Lagerstätte of Morocco. Palaeogeography Palaeoclimatology Palaeoecology 460, $122-129$.

Martin, E.L.O., Pittet, B., Gutiérrez-Marco, J.C., Vannier, J., El Hariri, K., Lerosey-Aubril, R., Masrour, M., Nowak, H., Servais, T., Vandenbroucke, T.R.A., Van Roy, P., Vaucher, R., Lefebvre, B., 2016. The Lower Ordovician Fezouata Konservat-Lagerstätte from Morocco: age, environment and evolutionary perspectives. Gondwana Research 34, 274-283.

Mooi, R., David, B., 1998. Evolution within a bizarre phylum: homologies of the first echinoderms. American Zoologist 38, 965-974.

Mooi, R., David, B., 2008. Radial symmetry, the anterior/posterior axis, and echinoderm Hox genes. Annual Review of Ecology Evolution, and Systematics 39, 43-62.

Ou, Q., Conway Morris, S., Han, J., Zhang, J., Liu, J., Chen, A., Zhang, X., Shu, D.G., 2012. Evidence for gill slits and a pharynx in Cambrian vetulicolians: implications for the early evolution of deuterostomes. BioMed Central Biology 10, 81.

Rahman, I.A., Jefferies, R.P.S., Südkamp, W.H., Smith, R.D.A., 2009. Ichnological insights into mitrate palaeobiology. Palaeontology 52, 127-138.

Rozhnov, S.V., Parsley, R.L., 2017. A new cornute (Homalozoa: Echinodermata) from the uppermost middle Cambrian (Stage 3, Furongian) from northern Iran: its systematics and functional morphology. Paleontological Journal 51, 500-509.

Shu, D.G., Conway Morris, S., Han, J., Chen, L., Zhang, X.L., Zhang, Z.F., Liu, H.Q., Li, Y., Liu, J.N., 2001. Primitive deuterostomes from the Chengjiang Lagerstätte (Lower Cambrian, China). Nature 414, 419-424. 
Shu, D.G., Conway Morris, S., Han, J., Zhang, Z.F., Liu, J.H., 2004. Ancestral echinoderms from the Chengjiang deposits of China. Nature 430, 422-428.

Smith, A.B., 2005. The pre-radial history of echinoderms. Geological Journal 40, 255-280.

Sutton, M.D., Briggs, D.E.G., Siveter, D.J., Siveter, D.J., Gladwell, D.J., 2005. A starfish with three-dimensionally preserved soft parts from the Silurian of England. Proceedings of the Royal Society B 272, 1001-1006.

Swalla, B.J., Smith, A.B., 2008. Deciphering deuterostome phylogeny: molecular, morphological and palaeontological perspectives. Philosophical Transactions of the Royal Society B 363, $1557-1568$.

Ubaghs, G., 1968. Stylophora, in: Moore, R.C. (Ed.), Treatise on Invertebrate Paleontology. Part S. Echinodermata 1. Geological Society of America and University of Kansas Press, Lawrence, S495-S565.

Ubaghs, G., 1975. Early Paleozoic echinoderms. Annual Review of Earth and Planetary Sciences 3, 79-98.

Van Roy, P., Briggs, D.E.G., 2011. A giant Ordovician anomalocaridid. Nature 473, 510-513.

Van Roy, P., Orr, P.J., Botting, J.P., Muir, L.A., Vinther, J., Lefebvre, B., El Hariri, K., Briggs, D.E.G., 2010. Ordovician faunas of Burgess Shale type. Nature 465, 215-218.

Van Roy, P., Briggs, D.E.G., Gaines, R.R., 2015. The Fezouata fossils of Morocco; an extraordinary record of marine life in the Early Ordovician. Journal of the Geological Society $172,541-549$.

Vaucher, R., Martin, E.L.O., Hormière, H., Pittet, B., 2016. A genetic link between Konzentratand Konservat-Lagerstätten in the Fezouata Shale (Lower Ordovician, Morocco). Palaeogeography Palaeoclimatology Palaeoecology 460, 24-34. 
Vinther, J., Van Roy, P., Briggs, D.E.G., 2008. Machaeridians are Palaeozoic armoured annelids. Nature 451, 185-188.

Vinther, J., Smith, M.P., Harper, D.A.T., 2011. Vetulicolians from the Lower Cambrian Sirius Passett Lagerstätte, North Greenland, and the polarity of morphological characters in basal deuterostomes. Palaeontology 54, 771-719.

Vinther, J., Parry, L., Briggs, D.E.G., Van Roy, P., 2017. Ancestral morphology of crown-group molluscs revealed by a new Ordovician stem aculiferan. Nature 542, 471-475.

Zamora, S., Rahman, I.A., 2014. Deciphering the early evolution of echinoderms with Cambrian fossils. Palaeontology 57, 1105-1119.

Zamora S., Lefebvre B., Alvaro J.J., Clausen S., Elicki O., Fatka O., Jell P., Kouchinsky A., Lin J.P., Nardin E., Parsley R.L., Rozhnov S., Sprinkle J., Sumrall C.D., Vizcaïno D., Smith A.B., 2013. Cambrian echinoderm diversity and palaeobiogeography, in: Harper, D.A.T., Servais, T. (Eds.), Early Palaeozoic Biogeography and Palaeogeography. Geological Society of London Memoirs 38, 157-171.

\section{Figure captions}

Fig. 1. The two current interpretations of stylophoran morphology and their implications for softtissue anatomy, based on the cornute Phyllocystis blayaci (Lower Ordovician, France). A-C. H1, stylophorans as typical echinoderms with a single feeding arm. D-F. H2, stylophorans as preradial echinoderms with a hemichordate-like stalk. A, D. Basic anatomical features deduced from skeletal morphology. B, E. Reconstructions of soft tissue anatomy along a longitudinal 
451 section of the stylophoran appendage. C, F. Three-dimensional reconstructions of the soft tissue

452 anatomy in the distal part of the stylophoran appendage.

453

454 Fig. 2. The two current interpretations of stylophoran phylogenetic position within 455 ambulacrarian deuterostomes. H1, stylophorans as typical echinoderms with a single feeding 456 arm. H2, stylophorans as pre-radial echinoderms with a hemichordate-like stalk.

457

458

459

460

461

462

463 464 rocks.

465

466

467

468

469

470

471

$472 \quad 2 \mathrm{~mm}(\mathrm{~B})$.

Fig. 3. Geographic and geologic context of Bou Izargane locality. On the maps (left), Ordovician outcrops in north-western Africa and in the Zagora area are indicated in green. The red star shows the location of Bou Izargane hill. On the right, partial stratigraphic column of the Fezouata Shale, showing the position of the Bou Izargane excavation. The left column indicates sea level changes. Numbers along the right column indicate the height (in meters) above the Cambrian/Ordovician boundary. The colors used in the log correspond to those of outcropping

Fig. 4. Arthropods with soft-tissue preservation collected in the same lens as cornute stylophorans with soft parts, late Tremadocian (Lower Ordovician), Bou Izargane, Zagora area (Morocco). A. Two associated specimens of the marrellomorph Furca sp. (AA.BIZ15.OI.364).

B-C. Two specimens of the trilobite Bavarilla zemmourensis. B. Arrows indicate four locomotory appendages below the thorax (AA.BIZ15.OI.181). C. The arrow shows one frontal appendage at the anterior extremity of the cephalon (AA.BIZ15.OI.16). Scale bars, $5 \mathrm{~mm}$ (A, C); 
474

475

476

477

478

479

480

481

482

Fig. 5. Thoralicystis n. sp. from the Fezouata Shale, Lower Ordovician, Morocco (AA.BIZ15.OI.259). A-C. Complete specimen in lateral view. A. Composite photographic reconstruction. B. Composite SEM elemental map of Fe. C. Composite reconstruction of soft part anatomy based on camera lucida drawings, SEM elemental maps (Fe) and back-scattered electron micrographs. D-F. Magnified views of parts of the distal appendage outlined in (A-C). D. Back-scattered electron micrograph. The arrows indicate the position of tube feet. E. SEM elemental map showing the distribution of Fe. F. Reconstruction of the soft parts based on camera lucida drawings, SEM elemental maps (Fe) and back-scattered electron micrographs. pr. cavity, proximal cavity; pr. rings, proximal rings; styl., stylocone; wvs, water vascular system. Scale bars, $5 \mathrm{~mm}(\mathrm{~A}-\mathrm{C}) ; 1 \mathrm{~mm}(\mathrm{D}-\mathrm{F})$.

Fig. 6. Soft-tissue preservation in the distal appendage of the cornute stylophoran Thoralicystis n. sp. (AA.BIZ15.OI.259), late Tremadocian (Lower Ordovician), Bou Izargane, Zagora area (Morocco). A. Photographic view of the magnified area. B. Back-scattered electron micrograph showing the water vascular system (ambulacral canal, tube feet) and the second, more internal, longitudinal canal. Skeletal elements (biserial platelets, ossicles) are not visible. C-J. SEM elemental maps of Al (C), C (D), Fe (E), K (F), Mg (G), Na (H), O (I) and Si (J). Scale bars, 1 mm.

Fig. 7. Soft-tissue preservation in the test and proximal appendage of the cornute stylophoran Hanusia n. sp. (AA.BIZ15.OI.110), late Tremadocian (Lower Ordovician), Bou Izargane, Zagora area (Morocco). A. Composite photographic reconstruction of the specimen in lateral view. B. Composite reconstruction based on back-scattered electron micrographs. C. Reconstruction of 
497 the soft parts based on camera lucida drawings and back-scattered electron micrographs. bis. 498 platelets, biserial platelets. Scale bars, $5 \mathrm{~mm}$.

499

500 Fig. 8. Soft-tissue preservation in the proximal appendage of the cornute stylophoran Hanusia n. 501 sp. (AA.BIZ15.OI.80), late Tremadocian (Lower Ordovician), Bou Izargane, Zagora area 502 (Morocco). A. Specimen in upper view. B. Reconstruction of (A), based on camera lucida 503 drawings. C. Closer view of the proximal region of the appendage outlined in (A). D. 504 Reconstruction of (C), based on camera lucida drawings. pr. cavity, proximal cavity; pr. rings, 505 proximal rings. Scale bars, $1 \mathrm{~mm}$.

506

507 Fig. 9. Reconstruction of the cornute stylophoran Thoralicystis n. sp., late Tremadocian (Lower 508 Ordovician), Zagora area (Morocco), with the tube feet protruding beyond the cover plates. The 509 appendage is about $20 \mathrm{~mm}$ long. 
A

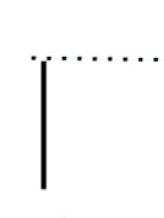
appendage

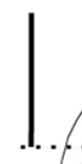
$\downarrow$ plane of section

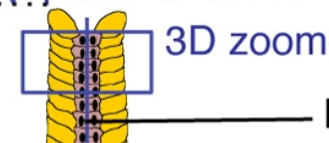
longitudinal groove
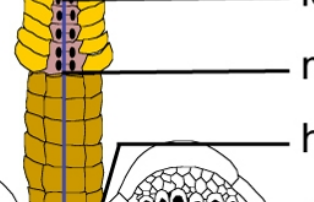
mouth hydropore

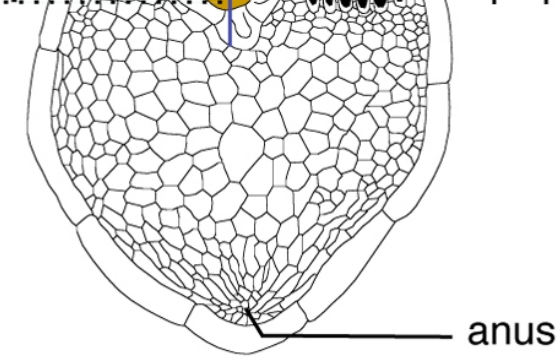

B water vascular system

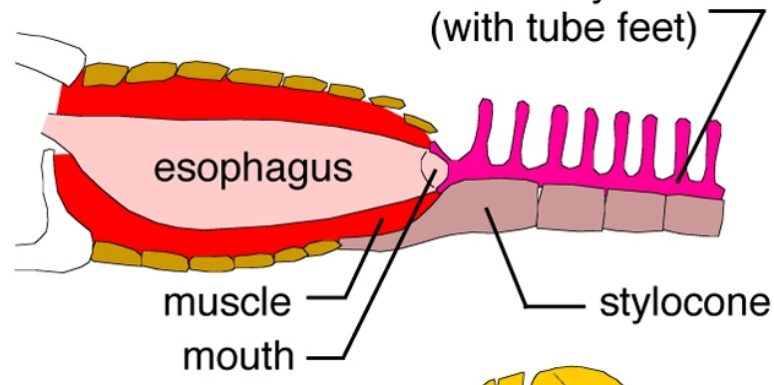

biserial platelets C

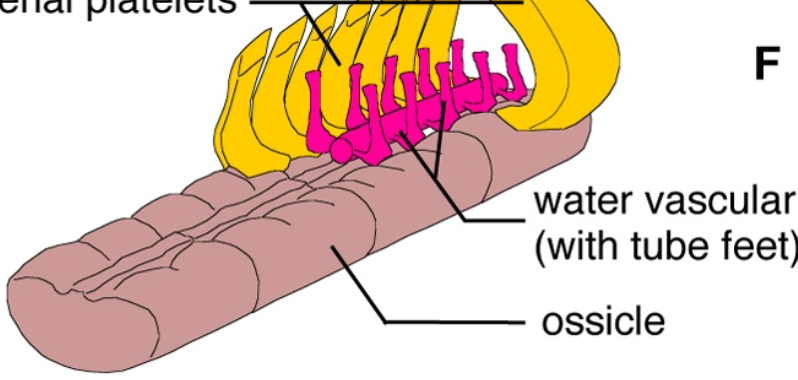

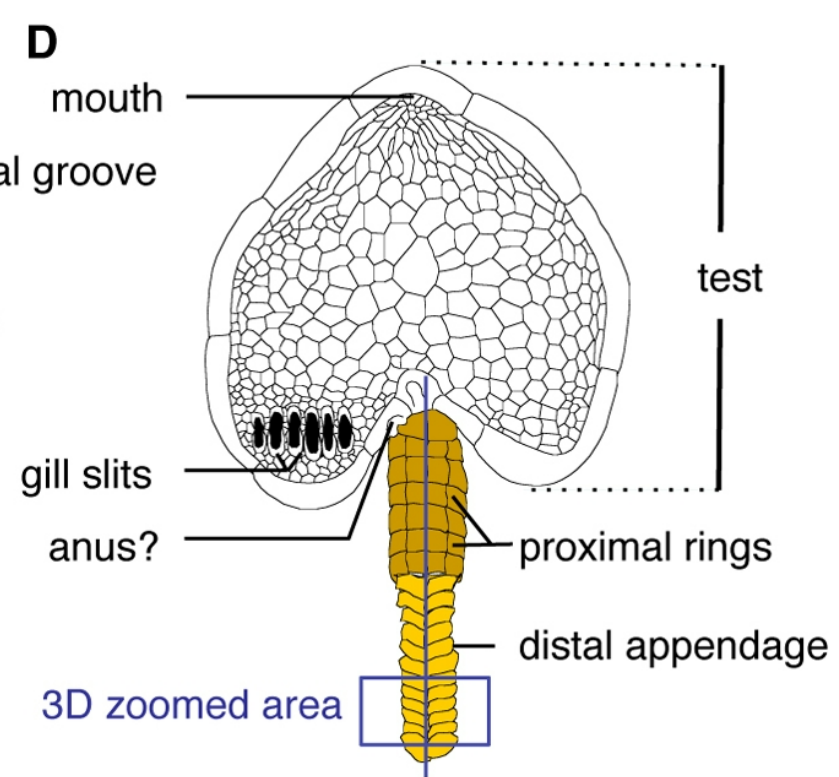

E plane of section $\uparrow$

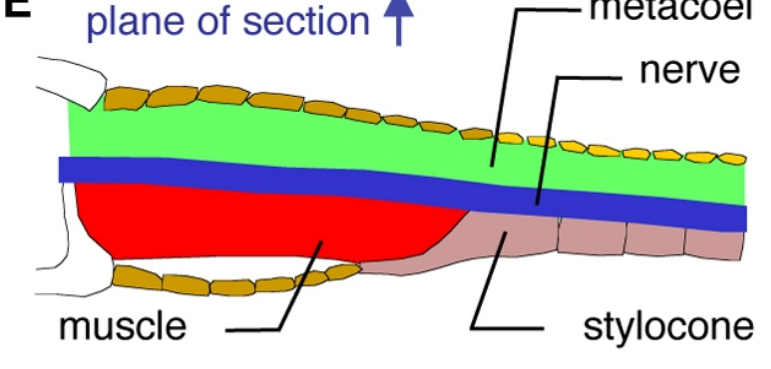

biserial platelets

F metacoel 

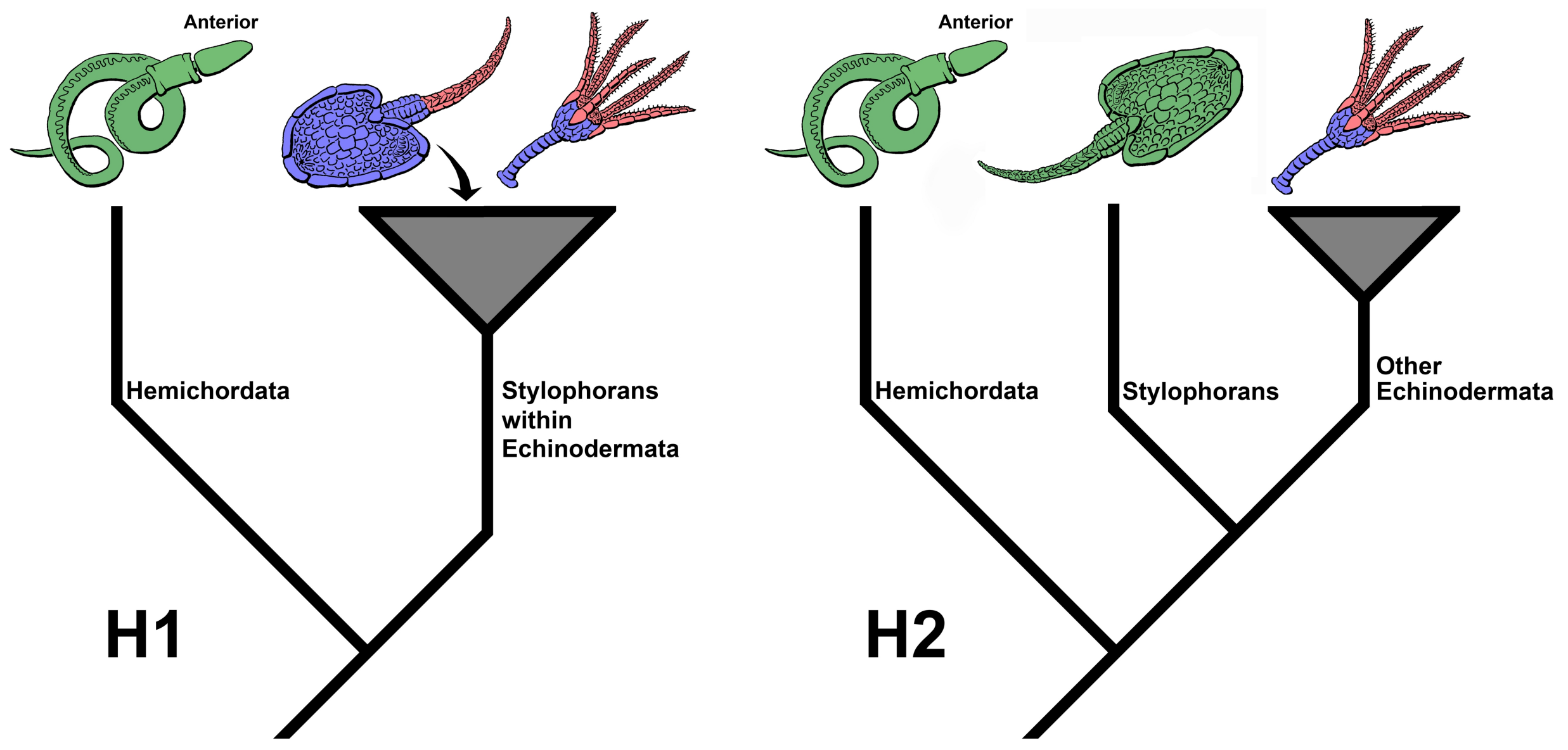

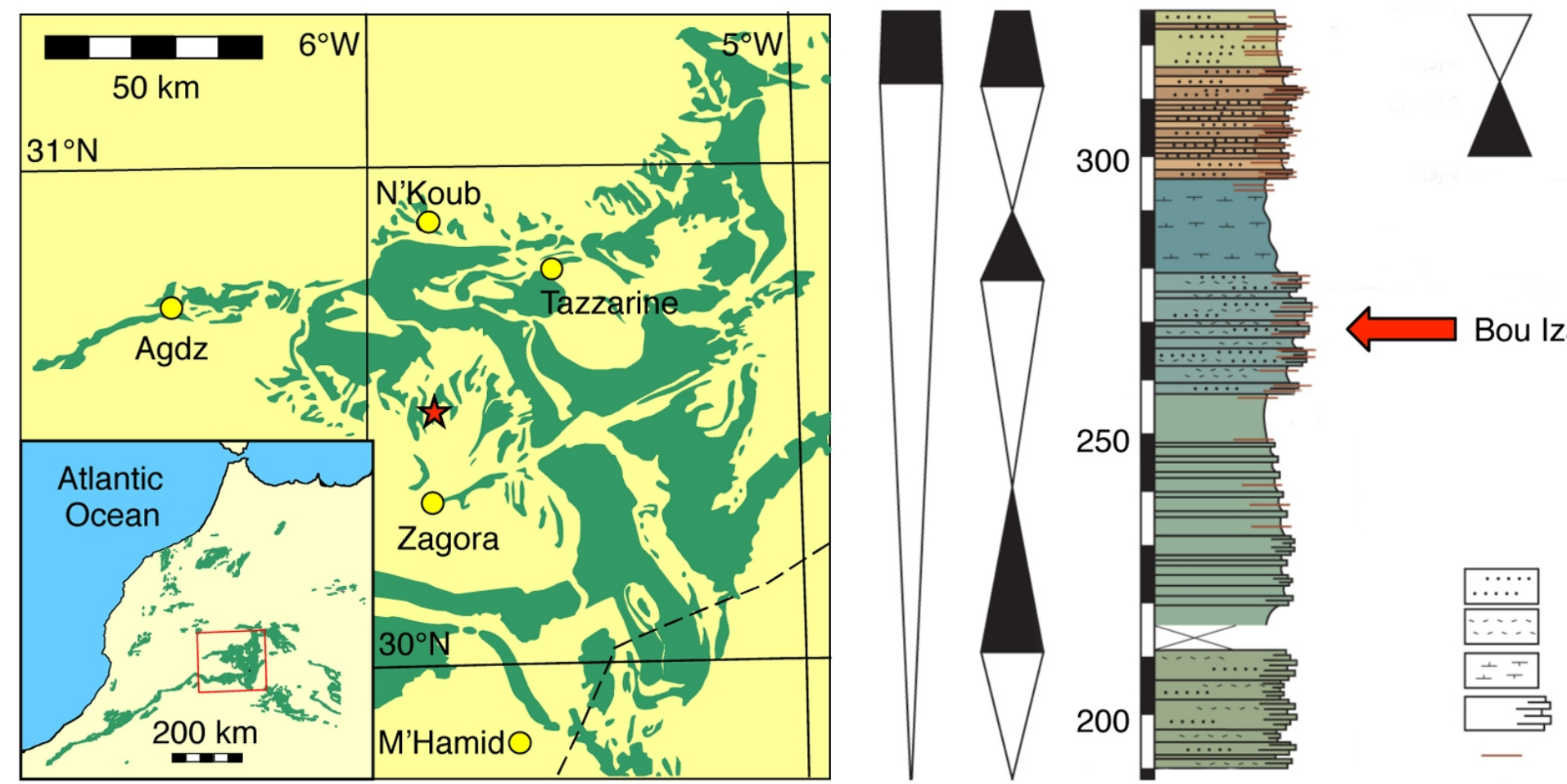

Shallowing trend

Deepening trend

Silty argillites

Micaceous argillites

Compacted/indurated argillites

Thinly bedded argillites

$\mathrm{mm}$ - to $\mathrm{cm}$-thick silty/sandy layers 


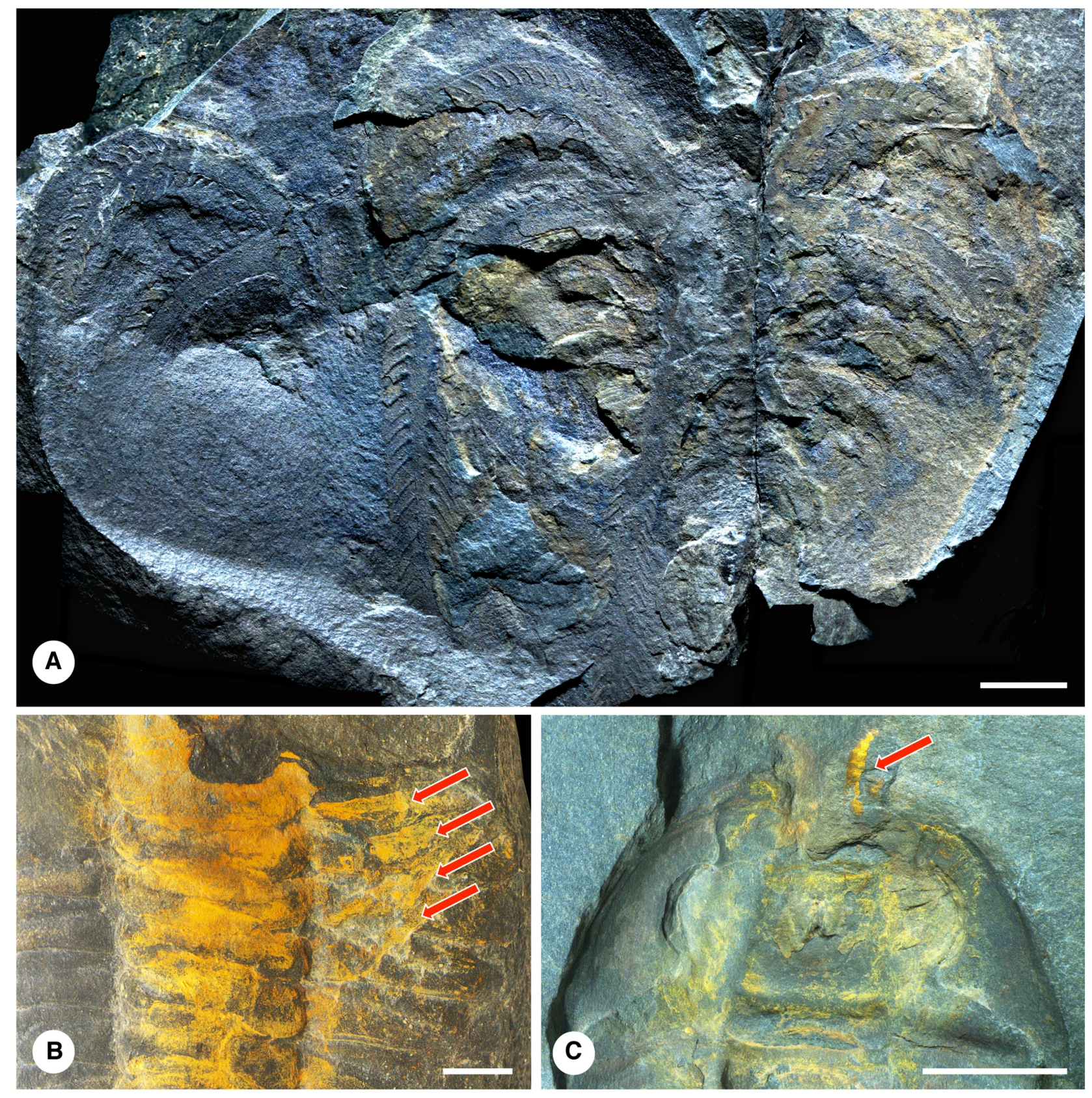



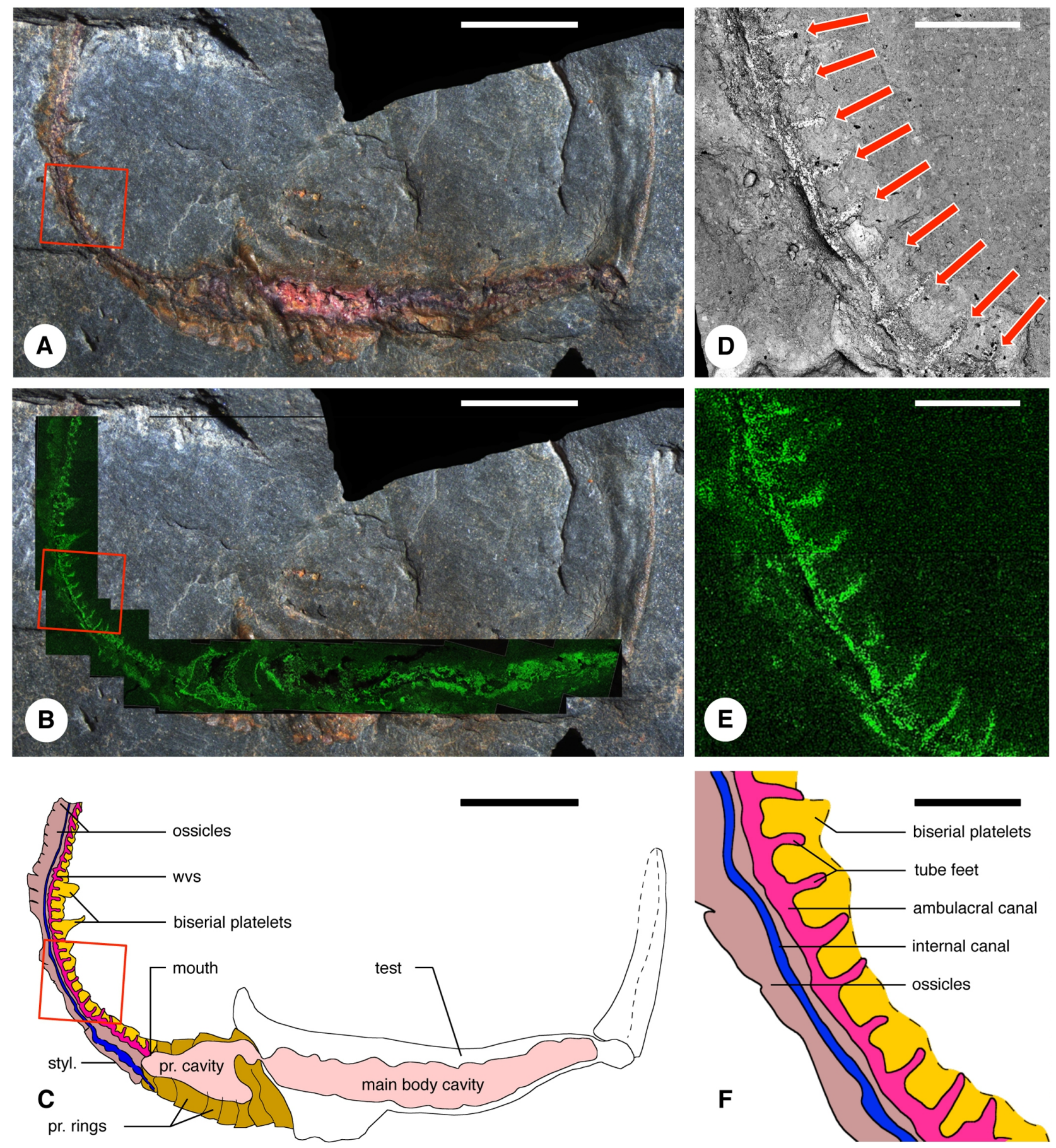

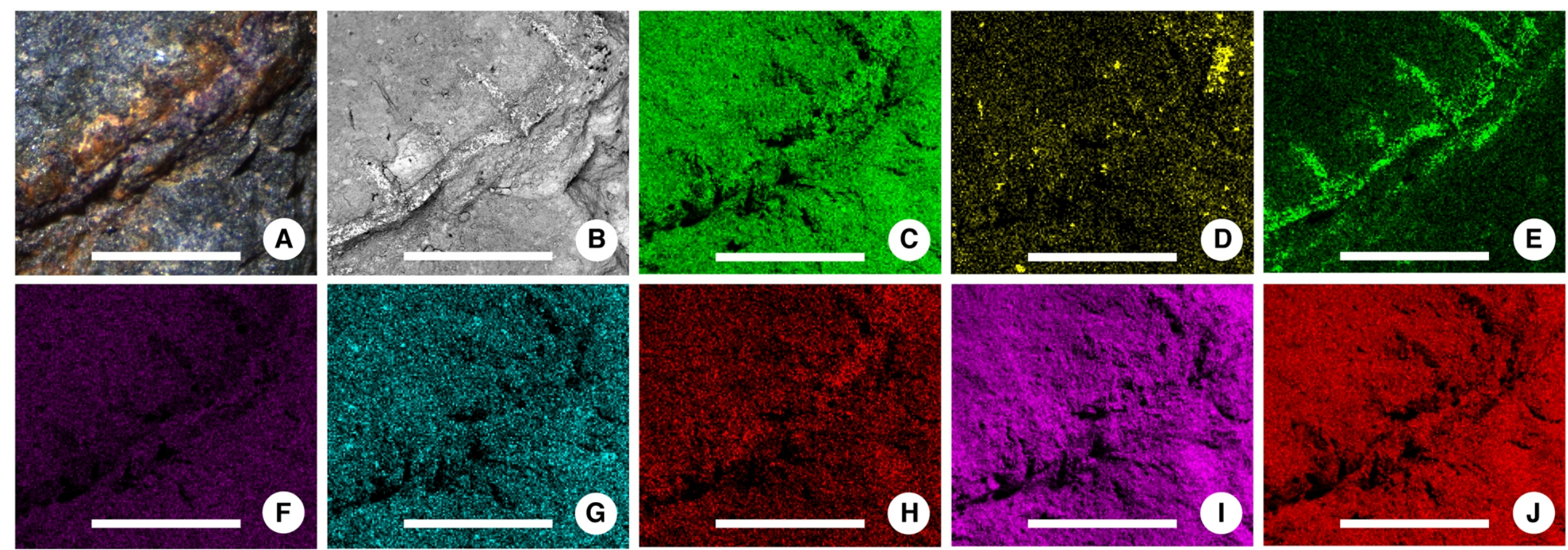

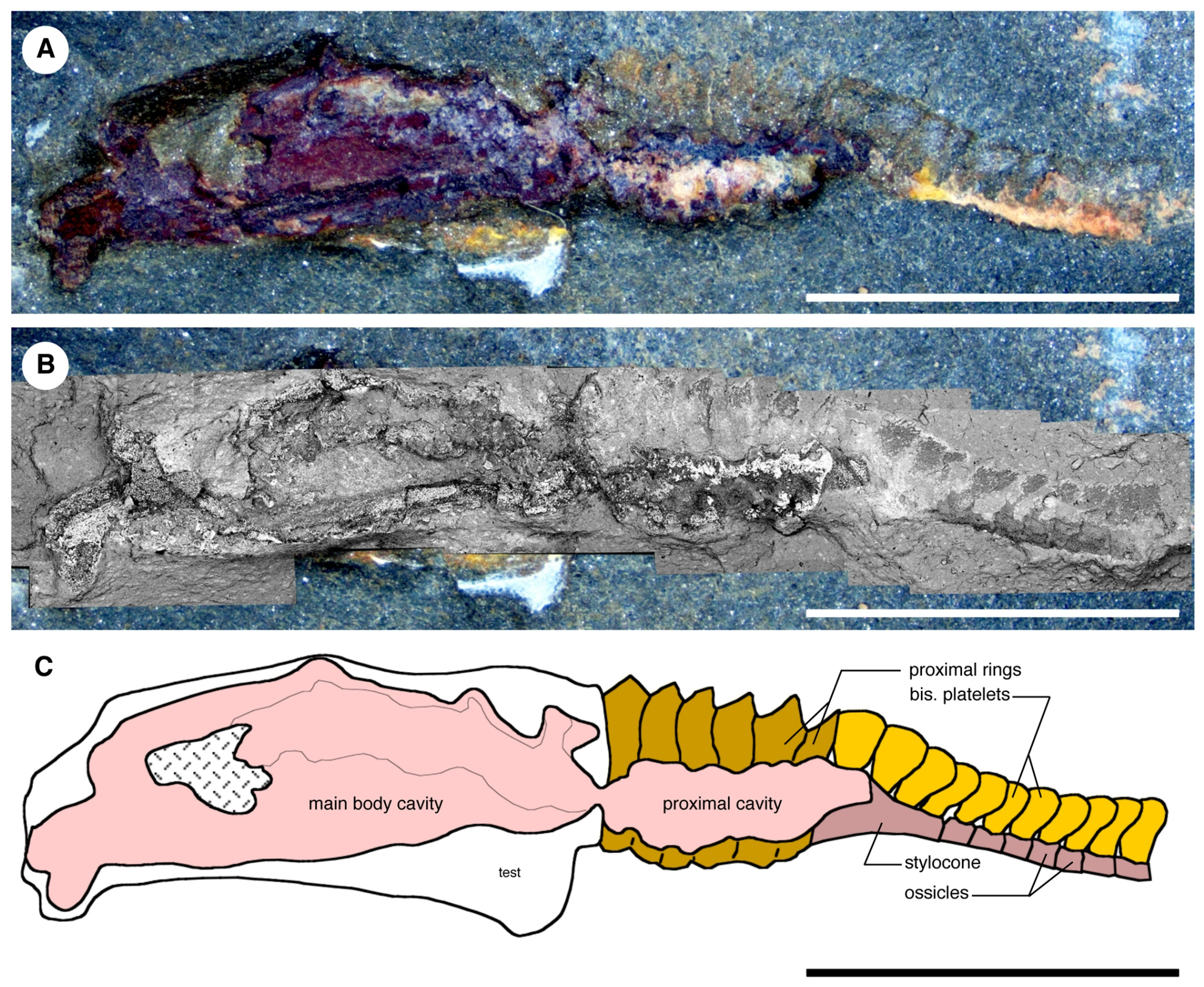

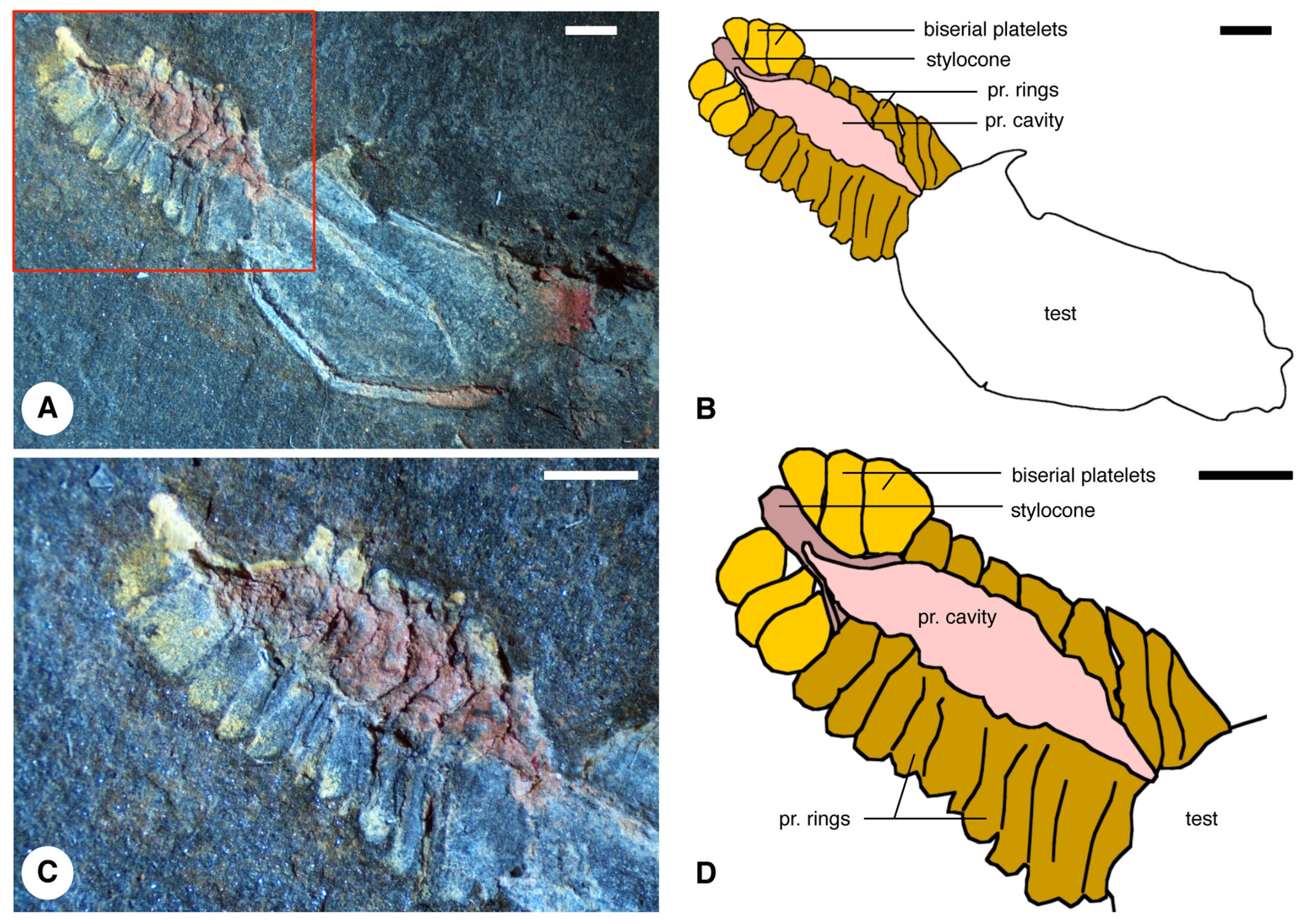


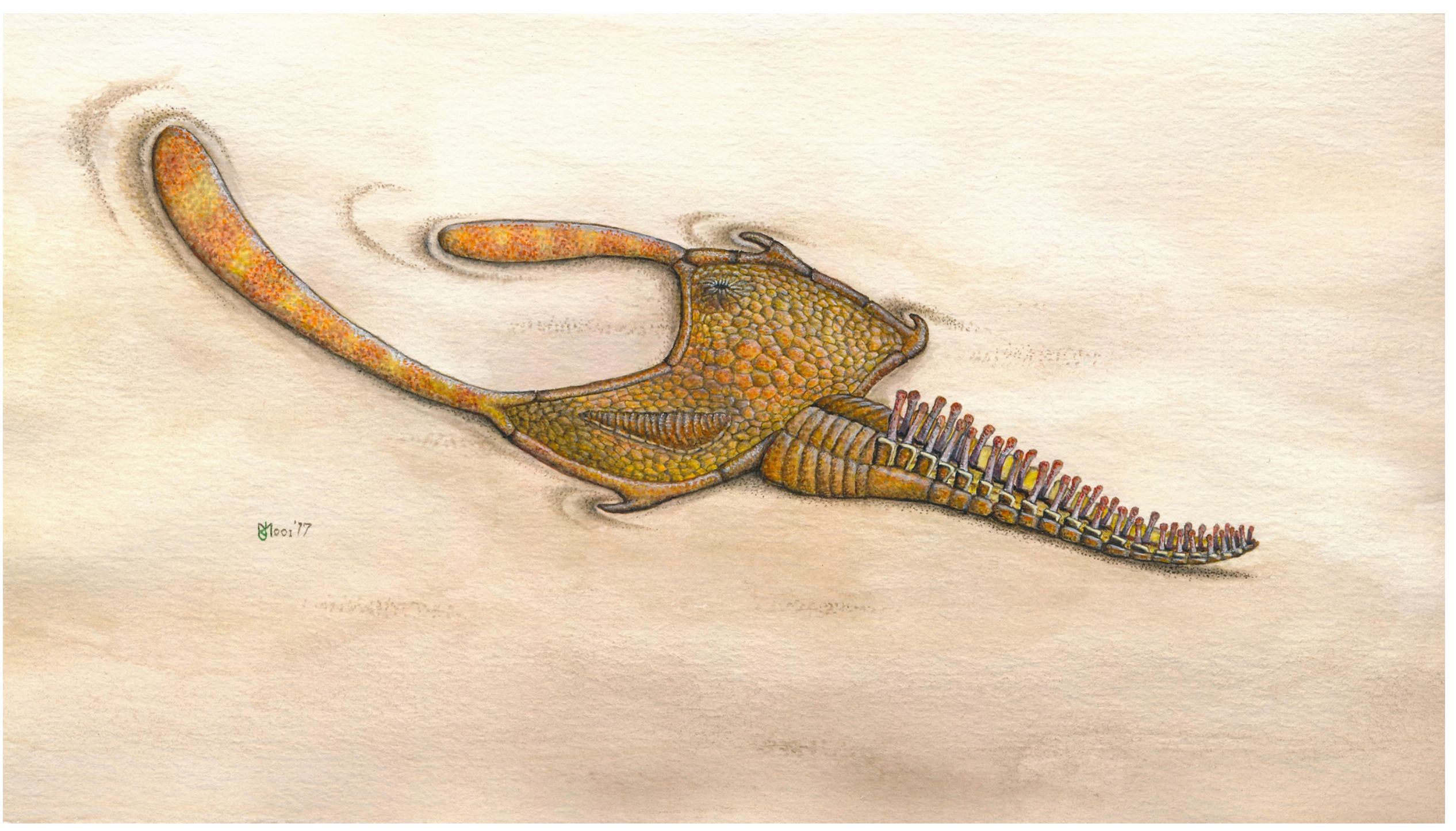

